\section{Reducing the economic burden of chronic disease requires major investment in public health}

This issue includes an illuminating paper entitled "Variation across Canada in the economic burden attributable to excess weight, tobacco smoking, and physical inactivity". The research used innovative economic modeling to estimate the economic burden of each of these three risk factors based on population attributable risk. The results and conclusions have important implications for public health practice and policy.

The first conclusion is that there has been a major shift in the distribution of economic burden by risk factor, with the economic burden attributable to smoking decreasing, while the burdens attributable to both excess weight and physical inactivity are increasing. A large part of this change is related to prevalence; smoking prevalence in Canada is now down to $17.5 \%$, while $46.1 \%$ of Canadians have excess weight and $43.6 \%$ are inactive. ${ }^{1}$ While there is still work to do in tobacco control, two questions arise: 1) what can we learn from the successes of tobacco control in decreasing prevalence of smoking in Canada that can be applied to obesity and physical inactivity? and 2) what type of investment will Canada need to make to catalyze a similar reduction in prevalence in excess weight and inactivity?

The second conclusion of the study is that there are geographic differences in the prevalence of risk factors across Canada. Specifically, due to the lower prevalence of smoking, excess weight and inactivity in British Columbia (BC), the economic burden per capita is lower than in any other province. Why do those living in $\mathrm{BC}$ smoke less, take part in more physical activity and have less excess weight? Specifically: 1) what characteristics of the social and physical environments create conditions that offer some protection to people living in BC? and 2) what public health investments have contributed to those protective environments?

\section{Lessons from tobacco control: Investing in social change}

While diseases associated with tobacco use are still of significant economic burden to Canadians, the paper by Krueger et al. clearly demonstrates that as smoking prevalence decreases, the economic burden is lessened. ${ }^{1}$ In $1965,49.5 \%$ of Canadians over the age of 15 smoked. The Government of Canada has been funding tobacco control interventions since the 1960s. First, public education was introduced. More comprehensive social marketing programming dominated the 1980s and 1990s. Predominantly voluntary restrictions on some of tobacco companies' marketing activities began briefly in the early 1970s under the threat of proposed legislation. However, concerted policy development combining legislation, regulation and health promotion began in the early 1980s, and the Tobacco Products Control Act was enacted in 1988, by which time smoking rates had dropped to $32 \%$. In 2001, the federal government invested $\$ 560$ million over five years to the Federal Tobacco Control Strategy (FTCS). Although intervention efforts had already seen an almost 50\% decline in smoking rates
Des investissements de grande envergure en santé publique pour réduire le poids économique des maladies chroniques

Le présent numéro traite d'un article fort instructif intitulé «Variation across Canada in the economic burden attributable to excess weight, tobacco smoking, and physical inactivity ${ }^{1}$. La recherche s'appuie sur un modèle novateur pour estimer le fardeau économique que représentent les trois facteurs de risque que sont l'excès de poids, le tabagisme et l'inactivité physique en fonction de leur fraction étiologique du risque dans la population. Les résultats et conclusions ont d'importantes conséquences sur les pratiques et les politiques en matière de santé publique.

Comme première conclusion, on peut lire qu'il y a eu une transformation importante dans la distribution du fardeau économique par facteur de risque, celui attribuable au tabagisme diminuant et ceux attribuables à l'excès de poids et à l'inactivité physique augmentant. Cette transformation s'explique en grande partie par l'évolution de la prévalence, laquelle a décliné à 17,5 \% au Canada pour le tabagisme tandis que la proportion de Canadiens qui présentent un excès de poids et qui sont inactifs atteint respectivement $46,1 \%$ et $43,6 \% 1$. Il reste certes du travail à faire du côté du tabagisme, mais deux questions émergent. Premièrement, quelles leçons peut-on tirer de l'efficacité des mesures de lutte contre le tabagisme à diminuer la prévalence du tabagisme au Canada et comment peut-on les appliquer à l'obésité et à l'inactivité physique? Deuxièmement, quel type d'investissement le Canada doit-il faire pour entraîner une réduction similaire de la prévalence de l'obésité et de l'inactivité?

La deuxième conclusion de l'étude porte sur les différences géographiques de la prévalence des facteurs de risque au Canada. Le cas de la Colombie-Britannique est particulièrement informatif : la prévalence du tabagisme, de l'excès de poids et de l'inactivité y entraîne un fardeau économique moindre par habitant que dans toute autre province. Pourquoi les BritannoColombiens fument-ils moins, sont-ils plus actifs et souffrent-ils moins d'obésité? De manière plus détaillée, quelles caractéristiques du milieu social et naturel créent les conditions propices à une certaine protection des Britanno-Colombiens? Quels investissements en santé publique ont contribué à créer un tel contexte favorable?

\section{Tirer des leçons de la lutte contre le tabagisme : investir dans les changements sociaux}

Même si les maladies associées au tabagisme constituent encore un fardeau économique considérable pour les Canadiens, l'article montre clairement que la prévalence du tabagisme est en baisse et fait donc diminuer le fardeau économique qui y est associé ${ }^{\text {. }}$ En 1965, 49,5 \% des Canadiens de plus de 15 ans fumaient. Le gouvernement du Canada finance les mesures de lutte contre le tabagisme depuis les années 1960. Il y a d'abord eu des campagnes éducatives, suivies de programmes globaux de marketing social qui ont dominé pendant les années 1980 et 
(in those 15 years and older) to $25 \%$, the commitment to tobacco control was clearly on the agenda, and the FTCS was a comprehensive, coordinated strategy including mass media, enforcement of regulations, surveillance and local projects. The investment was significant; the goal of reducing smoking rates to $20 \%$ in the first five years was achieved. ${ }^{2}$ Changing social norms is not easy; it requires significant effort and investment. The federal, provincial and territorial governments made a clear decision to invest in tobacco control. That investment has paid off in reduced health care and indirect costs. ${ }^{1}$

With respect to physical inactivity and excess weight, Canada appears to be at the stage now where it was with tobacco control in the 1970s. Focus on individual behaviour change through public education and social marketing dominates. Campaigns to promote physical activity, such as ParticipACTION, have been successful in raising public consciousness of physical activity. ${ }^{3}$ With respect to control of advertising of unhealthy foods and beverages in attempts to curb childhood obesity, the current norm is voluntary measures controlled by industry, which have been largely ineffective in curbing children's exposures. ${ }^{4}$ The exception is Quebec, where the Quebec Consumer Protection Act (QCPA) has prohibited all commercial marketing to children since 1980. This legislation has been shown to be more protective of Francophone children, who are less likely to be exposed to cross-border media from English Canada. ${ }^{5}$ School environments, an ideal site for protecting children, have made some progress. All provinces have adopted guidelines for healthy school food, yet only Ontario, BC, New Brunswick, Newfoundland and Nova Scotia have made them mandatory ${ }^{6}$ (school boards and municipalities within provinces have opted to adopt stronger measures in some cases, although compliance is uncertain as monitoring is often not mandated). Similarly, some provinces have adopted mandatory daily physical activity (DPA) policies, yet implementation is spotty, possibly due to low resources. ${ }^{7}$ In other words, Canada has a patchwork of policies with respect to improving food and physical activity environments, but no strong legislation to date. What is missing is a coordinated and well-resourced investment, including the resolve to take on industry (e.g., Big Food), who invest billions in marketing their products. ${ }^{8}$ This is where we can learn from tobacco control. We need collective environmental action for individual responsibility to take full effect and for comprehensive measures to be most effective. Action (with evaluation) is warranted before all of the evidence of intervention effectiveness has been established. ${ }^{9}$ Concerted policy development combining legislation, regulation and health promotion is needed to reverse the epidemics of physical inactivity and excess weight.

There is certainly no shortage of ideas as to potential environmental and policy approaches to addressing physical inactivity and excess weight. Even in (formerly) conservative Alberta, decision-makers support policy action to address physical inactivity, healthy eating and obesity, although the highest levels of support align with individually-focused policies such as public education. ${ }^{10}$ Federally and provincially, no Canadian jurisdiction has made a financial investment in chronic disease prevention that parallels the magnitude of the initial FTCS, despite the political rhetoric of reports and
1990. Les producteurs de cigarettes et tabac ont été nombreux à restreindre volontairement certaines de leurs activités promotionnelles au début des années 1970 devant la menace de la loi proposée. Cependant, la combinaison de législation, de réglementation et de promotion de la santé a favorisé la création concertée de politiques au début des années 1980, puis la Loi réglementant les produits du tabac a été adoptée en 1988 à un moment où le taux de tabagisme avait déjà baissé à $32 \%$. En 2001, le gouvernement fédéral a investi 560 millions de dollars sur cinq ans pour la Stratégie fédérale de lutte contre le tabagisme (SFLT). Même si les mesures de lutte avaient déjà entraîner une diminution du taux de tabagisme de près de la moitié, se situant alors à $25 \%$ chez ceux âgés de 15 ans ou plus, la lutte au tabagisme restait clairement une priorité : la SFLT était une stratégie globale et coordonnée faisant appel aux médias de masse, à la mise en application de la réglementation, à la surveillance et à des projets locaux. L'investissement était colossal, et on a réussi à faire encore baisser le taux de tabagisme à $20 \%$ au cours des cinq premières années ${ }^{2}$. Changer les normes sociales n'est pas chose facile : il faut beaucoup d'efforts et d'argent. Les gouvernements fédéral, provinciaux et territoriaux ont clairement décidé d'investir dans la lutte contre le tabac. L'investissement a permis de réduire les coûts indirects ainsi que les coûts des soins de santé1 associés à l'usage du tabac.

En ce qui concerne l'inactivité physique et l'excès de poids, le Canada semble en être là où il en était avec le tabagisme au cours des années 1970. On vise les changements comportementaux individuels par la sensibilisation et le marketing social. Les campagnes de promotion de l'activité physique comme ParticipACTION ont réussi à sensibiliser les citoyens à l'importance de l'activité physique ${ }^{3}$. Pour ce qui est de la lutte contre la promotion de boissons et d'aliments malsains pour contrer l'obésité infantile, il est de convention de laisser les entreprises prendre des mesures volontaires, mais trop peu de résultats ont été atteints ${ }^{4}$. Cependant, le Québec fait exception avec la Loi sur la protection du consommateur du Québec interdisant la publicité destinée aux enfants depuis 1980. Cette loi s'est révélée efficace à protéger les enfants francophones qui sont moins à risque d'être exposés aux médias anglocanadiens 5 . Il y a aussi eu des progrès dans les milieux scolaires, idéaux pour la protection des enfants. L'ensemble des provinces ont adopté des directives pour que les écoles offrent de la nourriture saine, mais seules l'Ontario, le Nouveau-Brunswick, Terre-Neuve-et-Labrador et la Nouvelle-Écosse les ont rendues obligatoires $^{6}$ (les conseils scolaires et les municipalités des provinces ont adopté des mesures plus contraignantes dans certains cas, mais il est difficile de savoir si on les respecte, car on n'effectue pas la surveillance nécessaire). De la même façon, dans certaines provinces, on a adopté des politiques d'activité physique obligatoire chaque jour, mais leur mise en æuvre est fragmentaire, probablement en raison du manque de ressources ${ }^{7}$. Autrement dit, le Canada compte sur un réseau plus ou moins disparate de politiques sur la saine alimentation et l'activité physique, mais aucune loi solide à cet effet. Il faut nettement investir d'importantes sommes de manière coordonnée et cibler les entreprises comme les géants de l'agroalimentaire qui investissent des milliards de dollars pour faire la promotion de leurs produits. ${ }^{8}$ C'est là où les leçons de la lutte contre le 
strategies that extoll the virtues of commitment to prevention. Lack of coordination means missed or misplaced opportunities and unrealized return on investment.

\section{Public health investments: Lessons on creating supportive environments}

But what of the regional variations in risk factor prevalence and associated costs? What characteristics of the social and physical environments create conditions that offer some protection to people living in $\mathrm{BC}$ ? As the paper $^{1}$ points out, favourable weather patterns may play some role in BC's higher physical activity levels, although the other Canadian jurisdiction with a higher than the Canadian average proportion of adults considered active in 2013 was Yukon! ${ }^{11}$ Perhaps a western culture promotes physical activity over weather for hardy Canadians. The most relevant insight is the significant investment in ActNow BC, a whole-of-government approach with the expressed goal of improving the health of the population, including a \$25 million infusion for addressing risk conditions and risk factors for chronic disease. However, political and financial support for ActNow has waned. Others have suggested that to build on the momentum, ActNow BC could be strengthened through legislation, learning from Quebec's Public Heath Law, allowing for accountability to long-term population health goals. $^{12}$

Returning to another lesson from tobacco control, it is worth noting that "complacency that past actions will serve well in the future may retard future progress"9 (p. 899). Complacency is a huge risk to public health. Progress in changing policy and environments to reduce chronic disease risk requires significant investment, both politically and financially. Clearly, a return on investment can be realized as risk prevalence drops. ${ }^{1}$ The economic argument is one more tool in advocating for healthy public policy. It's time for a well-resourced, legislated federal commitment and investment in reducing inactivity, improving healthy eating and reducing excess weight, working in parallel with tobacco (and alcohol) control so we can learn and build together. Canadians, and the sustainability of our health care system, are worth it.

\section{Kim D. Raine, PhD, RD, FCAHS \\ Centre for Health Promotion Studies, School of Public Health, University of Alberta, Edmonton, $A B$}

doi: $10.17269 / \mathrm{CJPH} .106 .5214$

\section{REFERENCES}

1. Krueger H, Krueger J, Koot J. Variation across Canada in the economic burden attributable to excess weight, tobacco smoking and physical inactivity. Can J Public Health 2015;106(4):e171-77.

2. Health Canada. Federal Tobacco Control Strategy: 2001-2011 Horizontal Evaluation: Final Report 2012. Ottawa, ON: Health Canada, 2012. Available at: http://www.hc-sc.gc.ca/ahc-asc/alt_formats/pdf/performance/eval/ftcsevaluation-sflt-eng.pdf (Accessed June 30, 2015).

3. Bauman A, Cavill N, Brawley L. ParticipACTION: The future challenges for physical activity promotion in Canada. Int J Behav Nutr Phys Act 2009;6:89. PMID: 19995460. doi: 10.1186/1479-5868-6-89.

4. Potvin Kent M, Dubois L, Wanless A. Self-regulation by industry of food marketing is having little impact during children's preferred television. Int J Pediatr Obes 2011;6(5-6):401-8. PMID: 21838571. doi: 10.3109/17477166.2011. 606321. tabagisme pourront être utiles. Il faut agir de manière collective sur les milieux de vie pour que la responsabilité individuelle prenne tout son sens et que les mesures globales mises de l'avant rapportent. Il est justifié d'agir (et d'évaluer les actions) avant que soient recueillies toutes les preuves de l'efficacité d'une intervention ${ }^{9}$. L'élaboration concertée de politiques combinant législation, réglementation et promotion de la santé est nécessaire si on veut endiguer l'épidémie d'inactivité physique et d'obésité.

Ce ne sont certainement pas les idées qui manquent quant aux méthodes et aux milieux à viser pour contrecarrer l'inactivité physique et l'excès de poids. Même dans l'Alberta (autrefois) conservatrice, les décideurs sont d'accord avec les mesures politiques pour contrer l'inactivité physique, la mauvaise alimentation et l'obésité, même si on est plus disposé à accepter des politiques centrées sur les citoyens, notamment des programmes de sensibilisation publique ${ }^{10}$. Ni le gouvernement fédéral ni les provinces n'ont fait d'investissement dans la prévention des maladies chroniques de la même ampleur que la SFLT malgré les grands discours sur les rapports produits et les stratégies élaborées où on louange les vertus de la prévention. Sans coordination, on risque de manquer des occasions ou d'agir au mauvais moment et ainsi de gaspiller l'argent investi.

\section{Investissements en santé publique : des leçons pour créer un contexte favorable}

Qu'en est-il des variations régionales dans la prévalence des facteurs de risque et des coûts associés? Quelles caractéristiques du milieu social et naturel créent les conditions propices à une certaine protection chez les Britanno-Colombiens? Comme le mentionne l'article ${ }^{1}$, la météo favorable peut jouer un certain rôle dans le taux supérieur d'activité physique en ColombieBritannique, bien que le deuxième endroit au Canada où la proportion moyenne d'adultes considérés comme actifs ayant dépassé la moyenne en 2013 soit le Yukon ${ }^{11}$ ! C'est peut-être plus la culture de l'ouest du pays qui favorise l'activité physique que la météo dans ce cas-ci. La piste la plus intéressante demeure cependant l'investissement colossal effectué dans ActNow BC, une approche pangouvernementale ayant pour but d'améliorer la santé de la population et prévoyant 25 millions de dollars pour étudier les conditions et facteurs de risque des maladies chroniques. Cependant, le soutien politique et financier pour ActNow s'est estompé. D'autres spécialistes ont suggéré qu'il fallait profiter de l'occasion pour créer un cadre législatif pour ActNow BC un peu à l'image de la Loi sur la santé publique du Québec de manière à obliger la reddition de compte sur les objectifs à long terme en matière de santé de la population ${ }^{12}$.

Il y a aussi une autre leçon à retenir de la lutte contre le tabac : « se contenter des actions passées en se disant qu'elles auront des bienfaits à l'avenir peut retarder les progrès $»^{9}(p .899)$ [traduction libre]. Une telle attitude complaisante constitue un énorme risque pour la santé publique. Il faut beaucoup d'argent et de volonté politique pour réaliser des progrès dans la transformation de la réglementation et des milieux de vie pour réduire les risques de maladies chroniques. Il ne fait aucun doute qu'on peut retirer des bénéfices nets si l'investissement fait baisser la prévalence des risques ${ }^{1}$. L'argument économique est un autre outil pour revendiquer des politiques publiques 
5. Potvin Kent M, Dubois L, Wanless A. A nutritional comparison of foods and beverages marketed to children in two advertising policy environments. Obesity 2012;20(9):1829-37. PMID: 21720425. doi: 10.1038/oby.2011.161.

6. Canadian Partnership Against Cancer. Prevention Policies Directory. Available at: http://www.cancerview.ca/cv/portal/Home/PreventionAndScreening/ PSProfessionals/PSPrevention/PreventionPoliciesDirectory/ (Accessed July 2, 2015).

7. Olstad DL, Campbell EJ, Raine KD, Nykiforuk CIJ. A multiple case history and systematic review of adoption, diffusion, implementation and impact of provincial daily physical activity policies in Canadian schools. BMC Public Health 2015;15:385. PMID: 25885026. doi: 10.1186/s12889-015-1669-6.

8. Brownell KD, Warner KE. The perils of ignoring history: Big tobacco played dirty and millions died. How similar is big food? Milbank Q 2009;87:259-94. PMID: 19298423. doi: 10.1111/j.1468-0009.2009.00555.x.

9. Yach D, McKee M, Lopez AD, Novotny T. Improving diet and physical activity: 12 lessons from controlling tobacco smoking. BMJ 2005;330 (7496):898-900. PMID: 15831879. doi: 10.1136/bmj.330.7496.898.

10. Raine KD, Nykiforuk CI, Vu-Nguyen K, Nieuwendyk LM, VanSpronsen E, Reed S, et al. Understanding key influencers' attitudes and beliefs about healthy public policy change for obesity prevention. Obesity 2014;22(11): 2426-33. PMID: 25131938. doi: 10.1002/oby.20860.

11. Canadian Fitness and Lifestyle Research Institute. Physical Activity Level of Canadians. Ottawa: CFLRI, 2015. Available at: http://www.cflri.ca/sites/ default/files/node/1374/files/CFLRI_Bulletin\%201_PAM\%202014-2015.pdf (Accessed July 2, 2015).

12. Anderson I, Beak C, Ling T, O'Reilly C, Roberts C. Building on the Momentum of ActNow BC. Vancouver, BC: Simon Fraser University, 2010. Available at: https://www.academia.edu/330294/Building_on_the_Momentum_of_ ActNow_BC (Accessed June 30, 2015). promotrices de santé. Le gouvernement fédéral doit dès maintenant s'engager à investir d'importantes sommes pour réduire l'inactivité, améliorer l'alimentation et combattre l'obésité en imitant ce qui se fait dans la lutte contre le tabac (et l'alcool) pour que nous puissions tous apprendre l'un de l'autre et avancer ensemble. La population canadienne ainsi que la viabilité de notre système de santé en valent la peine.

Kim D. Raine, Ph.D., Dt.P., MACSS

Centre for Health Promotion Studies, School of Public Health, University of Alberta, Edmonton (Alberta)

doi: $10.17269 / \mathrm{CJPH} .106 .5214$

\section{RÉFÉRENCES BIBLIOGRAPHIQUES}

1. Krueger H, Krueger J, Koot J. Variation across Canada in the economic burden attributable to excess weight, tobacco smoking and physical inactivity. Rev can santé publique 2015;106(4):e171-77.

2. Santé Canada. Stratégie fédérale de lutte contre le tabagisme 2001-2011 Évaluation horizontale. Ottawa, ON: Santé Canada, 2012. Sur Internet: http://www.hc-sc.gc.ca/ahc-asc/performance/eval/ftcs-evaluation-sflt-fra.php (consulté le 30 juin 2015).

3. Bauman A, Cavill N, Brawley L. ParticipACTION: The future challenges for physical activity promotion in Canada. Int J Behav Nutr Phys Act 2009; 6:89. PMID: 19995460. doi: 10.1186/1479-5868-6-89.

4. Potvin Kent M, Dubois L, Wanless A. Self-regulation by industry of food marketing is having little impact during children's preferred television. In J Pediatr Obes 2011;6(5-6):401-8. PMID: 21838571. doi: 10.3109/17477166.2011. 606321.

5. Potvin Kent M, Dubois L, Wanless A. A nutritional comparison of foods and beverages marketed to children in two advertising policy environments. Obesity 2012;20(9):1829-37. PMID: 21720425. doi: 10.1038/oby.2011.161.

6. Canadian Partnership Against Cancer. Prevention Policies Directory. Sur Internet: http://www.cancerview.ca/cv/portal/Home/PreventionAndScreening/ PSProfessionals/PSPrevention/PreventionPoliciesDirectory/ (consulté le 2 juillet 2015).

7. Olstad DL, Campbell EJ, Raine KD, Nykiforuk CIJ. A multiple case history and systematic review of adoption, diffusion, implementation and impact of provincial daily physical activity policies in Canadian schools. BMC Public Health 2015;15:385. PMID: 25885026. doi: 10.1186/s12889-015-1669-6.

8. Brownell KD, Warner KE. The perils of ignoring history: Big tobacco played dirty and millions died. How similar is big food? Milbank Q 2009;87:259-94. PMID: 19298423. doi: 10.1111/j.1468-0009.2009.00555.x.

9. Yach D, McKee M, Lopez AD, Novotny T. Improving diet and physical activity: 12 lessons from controlling tobacco smoking. BMJ 2005;330(7496): 898-900. PMID: 15831879. doi: 10.1136/bmj.330.7496.898.

10. Raine KD, Nykiforuk CI, Vu-Nguyen K, Nieuwendyk LM, VanSpronsen $\mathrm{E}$ Reed S, et al. Understanding key influencers' attitudes and beliefs about healthy public policy change for obesity prevention. Obesity 2014;22(11): 2426-33. PMID: 25131938. doi: 10.1002/oby.20860.

11. Institut canadien de la recherche sur la condition physique et le mode de vie. Physical Activity Level of Canadians. Ottawa, ON: CFLRI, 2015. Sur Internet: http://www.cflri.ca/sites/default/files/node/1374/files/CFLRI_Bulletin\%201_ PAM\%202014-2015.pdf (consulté le 2 juillet 2015).

12. Anderson I, Beak C, Ling T, O'Reilly C, Roberts C. Building on the Momentum of ActNow BC. Vancouver, BC: Simon Fraser University, 2010. Sur Internet: https://www.academia.edu/330294/Building_on_the_Momentum_of_ ActNow_BC (consulté le 30 juin 2015). 